Original Research Article

\title{
Efficacy and safety of topical $2 \%$ dorzolamide and $0.5 \%$ timolol in cases of open angle glaucoma in a tertiary care hospital of East Singhbhum: an observational, prospective and comparative study
}

\author{
Akash Chandra ${ }^{1 *}$, Manish Kumar ${ }^{1}$, Amrendra Narayan Mishra ${ }^{2}$
}

\begin{abstract}
${ }^{1}$ Department of Pharmacology, IGIMS, Patna, Bihar, India ${ }^{2}$ Department of Pharmacology, MGM Medical College \& Hospital, Jamshedpur, Jharkhand, India
\end{abstract}

Received: 17 April 2018

Accepted: 22 May 2018

*Correspondence to:

Dr. Akash Chandra,

Email: drakash1984@gmail.com

Copyright: (C) the author(s), publisher and licensee Medip Academy. This is an openaccess article distributed under the terms of the Creative Commons Attribution NonCommercial License, which permits unrestricted noncommercial use, distribution, and reproduction in any medium, provided the original work is properly cited.

\begin{abstract}
Background: Present study was undertaken to evaluate and compare the efficacy and side effects of $2 \%$ dorzolamide and $0.5 \%$ timolol in patients with open angle glaucoma.

Methods: There were 60 randomly selected patients were equally divided into Group I $(n=30)$ and Group II $(n=30)$. Further both groups were divided into IA $(n=10)$, IB $(n=20)$, IIA $(n=10)$ and IIB $(n=20) .2 \%$ Dorzolamide hydrochloride in Group IA and IIA and $0.5 \%$ Timolol maleate in Group IB and IIB was administered for 24 weeks. Patients were evaluated for general and ocular examinations on day of enrolment and then at the end of 1st, 4th, 8th and 24th week. Adverse effects of the drug during study period were also noted. Mean $\pm S D$, $\mathrm{t}$ value, $\mathrm{p}$ value and comparison between groups were analysed by graph pad software.

Results: At the end of 24 weeks difference in mean reduction of IOP was not significant with $6.2 \pm 1.85 \mathrm{~mm} \mathrm{Hg}$ (Right eye) and $5.55 \pm 1.68 \mathrm{~mm} \mathrm{Hg}$ (left eye) and $4.72 \pm 2.97 \mathrm{~mm} \mathrm{Hg}$ (Right eye) and $5.37 \pm 1.24 \mathrm{~mm} \mathrm{Hg}$ (left eye) in Group IA and Group IIA respectively. At the end of 24 weeks difference in mean reduction of IOP was not significant with $5.06 \pm 1.62 \mathrm{~mm} \mathrm{Hg}$ (Right eye) and $4.40 \pm 1.96 \mathrm{~mm} \mathrm{Hg}$ (left eye) and $4.30 \pm 1.41 \mathrm{~mm} \mathrm{Hg}$ (Right eye) and $4.12 \pm 2.08 \mathrm{~mm} \mathrm{Hg}$ (left eye) in Group IB and Group IIB respectively. Fall in both systolic and diastolic blood pressure in both the groups were significant. Both drug regimens were welltolerated, and no serious drug-related adverse effects were reported.

Conclusions: Dorzolamide was more efficacious for reduction of intra ocular pressure, well-tolerated, had low allergic response and had a favourable ocular, cardiovascular and respiratory safety profile than Timolol.
\end{abstract}

Keywords: Intraocular pressure, Topical 2\% dorzolamide, Topical $0.5 \%$ timolol, Primary open angle glaucoma

\section{INTRODUCTION}

Glaucoma is a chronic progressive optic neuropathy caused by a group of ocular conditions which lead to damage of optic nerve with loss of visual function. ${ }^{1}$ Raised intraocular pressure is essentially due to an increased resistance to the circulation of the aqueous at the pupil or to its drainage through the angle of the anterior chamber. ${ }^{2}$

Normal intraocular pressure depends up on the formation and outflow of aqueous humour which is under the control of parasympathetic and sympathetic activities of the autonomic nervous system. Normal intraocular pressure is maintained at $10-21 \mathrm{~mm}$ of $\mathrm{Hg}^{3}$

The diagnosis of glaucoma is made after looking for a combination of clinical signs characteristic change in the optic nerve head, abnormalities in visual field and a rise in intraocular pressure. ${ }^{4}$ The type of glaucoma is determined by the clinical features and the status of anterior chamber angle as determined by gonioscopy. ${ }^{5}$

Primary open angle glaucoma (POAG) characteristically has an adult onset and is a bilateral almost symmetrical 
disease. Ocular examination shows an open anterior chamber angle, optic nerve head changes, visual field damage and an intraocular pressure of more than $21 \mathrm{~mm}$ $\mathrm{Hg}$. POAG is the commonest form of glaucoma in Caucasians and Africans. It occurs in the elderly rarely being seen earlier than 40years of age. The inheritance is thought to be multi factorial and polygenic. ${ }^{6}$

\section{Timolol Maleate}

It is a non selective $\beta_{1}$ and $\beta_{2}$ adrenergic antagonist. It reduces intra ocular pressure in normal and glaucomatous eyes without changing the visual acuity and accommodation on pupil size (Katz et al., 1976, Radius et al., 1978). ${ }^{7,8}$ It is supplied in $0.25 \%$ and $0.5 \%$ concentration, which are administered every 12 to 24 hours. It penetrates the eye rapidly and following topical administration IOP begin to fall in $1 / 2$ to 1 hour, reaches a maximum in 2 hours and returns to baseline in 24 to 48 hours. The aqueous production is reduced to $47 \%$ after one week of timolol treatment but only $25 \%$ after one year of treatment. This process has been called "Long Term Drift" and is due to a time dependent decrease in acellular sensitivity to adrenergic antagonist. ${ }^{9}$

\section{Dorzolamide}

It is a topically used carbonic anhydrase inhibitor developed to circumvent systemic side effects of acetazolamide. It is available in $2 \%$ eye drops. It lowers intra ocular tension by $20 \%$; Ocular stinging, burning sensation, itching, bitter taste are side effects. It causes shallowing of the anterior chamber and leads to transient Myopia. It does not give change in pupil size, no diminution of vision in dim light and in patient with cataract. ${ }^{10}$

The present study was undertaken to evaluate and compare the efficacy and side effects of these two drugs in patients with Glaucoma and increased intra ocular pressure.

\section{METHODS}

Study was carried out at Department of Pharmacology and Ophthalmology of MGM Medical College and Hospital, Jamshedpur, East Singhbhum, Jharkhand, India. Duration of the study was 12 months (from March 2013 to February 2014). There were 60 diagnosed cases of primary open angle glaucoma were randomly selected from the Department of Ophthalmology (outpatient and indoor) of MGM Medical College and Hospital, Jamshedpur, Jharkhand. This study was approved from Institutional Ethics Committee of MGM Medical College and Hospital.

\section{Inclusion criteria}

- Patients of all age above 35 years and all sex were included in this study.

- Patients of primary open angle glaucoma with IOP between 20 to $40 \mathrm{~mm}$ of $\mathrm{Hg}$.

\section{Exclusion criteria}

- Patients had glaucoma other than primary open angle, other ocular diseases or history of intraocular surgery.

- Patients on systemic beta-blockers.

- Patients suffering from obstructive pulmonary disease or hypertension/hypotension

\section{Plan of study}

The randomly selected patients $(n=60)$ were equally divided into two groups Group I (IOP between 20 to 30 $\mathrm{mm}$ of $\mathrm{Hg}, \mathrm{n}=30$ ) and Group II (IOP between 31 to $40 \mathrm{~mm}$ of $\mathrm{Hg}, \mathrm{n}=30$ ) according to their intra-ocular pressure (IOP) measured by Schiotz tonometer. Further both group divided into IA $(n=10)$, IB $(n=20)$, IIA $(n=10)$ and IIB $(n=20)$.

a) Group IA and IIA- 2\% Dorzolamide hydrochloride one drop thrice daily in both eyes was administered.

b) Group IB and IIB- $0.5 \%$ Timolol maleate one drop twice daily in both eyes was administered.

During each visit following examinations were done on day of enrolment and then at the end of $1^{\text {st }}, 4^{\text {th }}, 8^{\text {th }}$ and $24^{\text {th }}$ week.

a) History and Chief complaints: The history of any ocular or systemic and complaints suggestive of narrow angle and open-angle glaucoma. Duration of illness and family history of glaucoma, if any, were noted. Antiglaucoma medication, if taken previously was also noted.

b) General examination: includes pulse rate, heart rate and blood pressure.

c) Ocular examination: includes external examination by torch light, slit-lamp examination, Distant visual acuity tested by illuminated Snellen's chart, Schiotz tonometry, Gonioscopy, fundus examination and field analysis by Octopus auto-field analyser, Ophthalmoscopy and slit lamp biomicroscopy.

d) Any complaint regarding adverse effects of the drug during study period was noted.

All the patients were instructed not to administer their eyedrops on the morning of the check-up visits $\left(1^{\text {st }}, 4^{\text {th }}, 8^{\text {th }}\right.$ and $24^{\text {th }}$ week) in order to measure drug efficacy 12 hours after the previous evening dose.

\section{Statistical analysis}

Statistical analysis of data obtained were presented in tabular form. Mean $\pm S D$, $t$ value, $p$ value and comparison between groups were done by Graph Pad software. $p$ value $<0.05$ was considered significant.

\section{RESULTS}

In Table 1, Group I and II, male patients were 14 (46.75\%) and female patients were $16(53.25 \%)$ respectively in both 
the groups. Mean age was $63.6 \pm 8.14$ years, $61.2 \pm 9.6$ years, $63.3 \pm 10.56$ years and $57.5 \pm 10.4$ years in Group IA, IB, IIA and IIB patients.

Table 1: Age and sex distribution.

\begin{tabular}{|lllll|}
\hline $\begin{array}{l}\text { Characteristics } \\
\text { of pts }\end{array}$ & $\begin{array}{l}\text { Group } \\
\text { IA }\end{array}$ & $\begin{array}{l}\text { Group } \\
\text { IB }\end{array}$ & $\begin{array}{l}\text { Group } \\
\text { IIA }\end{array}$ & $\begin{array}{l}\text { Group } \\
\text { IIB }\end{array}$ \\
$\begin{array}{l}\text { Total no. of } \\
\text { patients entering } \\
\text { the study }\end{array}$ & 10 & 20 & 10 & 20 \\
\hline Male & 3 & 11 & 4 & 10 \\
\hline Female & 7 & 9 & 6 & 10 \\
\hline Mean age & $63.6 \pm$ & 61.2 & 63.3 & 57.5 \\
& 8.14 & \pm 9.60 & \pm 10.56 & \pm 10.40 \\
\hline
\end{tabular}

In Table 2, the mean IOP of Group IA, IB, IIA, IIB in the right and left respectively was $27.02 \pm 3.86$ and $25.95 \pm 2.16$, $25.93 \pm 3.67$ and $24.17 \pm 2.07,30.0 \pm 6.31$ and $33.02 \pm 1.09$,
$33.33 \pm 2.53$ and $32.79 \pm 4.31 \mathrm{~mm} \mathrm{Hg}$ (at pre-treatment), $22.32 \pm 2.80$ and $21.89 \pm 2.01,21.06 \pm 3.12$ and $20.63 \pm 1.68$, $24.92 \pm 5.18$ and $26.89 \pm 2.51,29.51 \pm 2.08$ and $29.87 \pm 4.62$ (at week 1), 20.02 \pm 1.98 and $20.08 \pm 1.71,20.49 \pm 1.61$ and $19.42 \pm 2.11,26.12 \pm 3.78$ and $27.43 \pm 2.86,29.41 \pm 2.81$ and $28.16 \pm 3.19 \mathrm{mmHg}$ (at week 4), 19.05 \pm 2.01 and $20.24 \pm 1.26,20.67 \pm 1.91$ and $19.46 \pm 1.74,25.91 \pm 3.51$ and $27.18 \pm 1.81,28.80 \pm 3.81$ and $28.42 \pm 3.19 \mathrm{~mm} \mathrm{Hg}$ (at week $8), \quad 20.82 \pm 2.46$ and $20.40 \pm 1.60, \quad 20.87 \pm 2.54$ and $19.77 \pm 1.93,25.28 \pm 3.59$ and $27.65 \pm 2.18,29.03 \pm 2.65$ and $28.67 \pm 3.56$ (at $24^{\text {th }}$ Week). Mean reduction of IOP was significant in all the groups and in both the eyes at the end of $24^{\text {th }}$ week of treatment in comparison to the pretreatment IOP.

In Table 3, mean reduction of IOP after 24 weeks in group IA and Group IB was significant in both the eyes. Mean reduction of IOP after 24 weeks in Group IIA and IIB was not significant in right eye but significant in left eye.

Table 2: Intraocular pressure in Group - IA, IB, IIA and IIB.

\begin{tabular}{|c|c|c|c|c|c|c|c|}
\hline & \multirow[b]{2}{*}{ Group } & \multicolumn{3}{|l|}{ Right Eye } & \multicolumn{3}{|l|}{ Left Eye } \\
\hline & & $\begin{array}{l}\text { IOP }(\mathrm{mm} \mathrm{Hg}) \\
(\text { Mean } \pm \text { SD })\end{array}$ & $\begin{array}{l}\text { t } \\
\text { value }\end{array}$ & $\begin{array}{l}\mathbf{p} \\
\text { Value }\end{array}$ & $\begin{array}{l}\text { IOP }(\mathrm{mm} \mathrm{Hg}) \\
(\text { Mean } \pm \text { SD })\end{array}$ & $\begin{array}{l}\mathrm{t} \\
\text { value }\end{array}$ & $\begin{array}{l}p \\
\text { value }\end{array}$ \\
\hline \multirow{4}{*}{ Pre-treatment } & IA & $27.02 \pm 3.86$ & & & $25.95 \pm 2.16$ & & \\
\hline & IB & $25.93 \pm 3.67$ & & & $24.17 \pm 2.07$ & & \\
\hline & IIA & $30.0 \pm 6.31$ & & & $33.02 \pm 1.09$ & & \\
\hline & IIB & $33.33 \pm 2.53$ & & & $32.79 \pm 4.31$ & & \\
\hline \multirow{4}{*}{ End of week 1} & IA & $22.32 \pm 2.80$ & & & $21.89 \pm 2.01$ & & \\
\hline & IB & $21.06 \pm 3.12$ & & & $20.63 \pm 1.68$ & & \\
\hline & IIA & $24.92 \pm 5.18$ & & & $26.89 \pm 2.51$ & & \\
\hline & IIB & $29.51 \pm 2.08$ & & & $29.87 \pm 4.62$ & & \\
\hline \multirow{4}{*}{ End of week 4} & IA & $20.02 \pm 1.98$ & & & $20.08 \pm 1.71$ & & \\
\hline & IB & $20.49 \pm 1.61$ & & & $19.42 \pm 2.11$ & & \\
\hline & IIA & $26.12 \pm 3.78$ & & & $27.43 \pm 2.86$ & & \\
\hline & IIB & $29.41 \pm 2.81$ & & & $28.16 \pm 3.19$ & & \\
\hline \multirow{4}{*}{ End of week 8} & IA & $19.05 \pm 2.01$ & & & $20.24 \pm 1.26$ & & \\
\hline & IB & $20.67 \pm 1.91$ & & & $19.46 \pm 1.74$ & & \\
\hline & IIA & $25.91 \pm 3.51$ & & & $27.18 \pm 1.81$ & & \\
\hline & IIB & $28.80 \pm 3.81$ & & & $28.42 \pm 3.19$ & & \\
\hline \multirow{4}{*}{ End of week 24} & IA & $20.82 \pm 2.46$ & 17.32 & $<0.001$ & $20.40 \pm 1.60$ & 12.87 & $<0.001$ \\
\hline & IB & $20.87 \pm 2.54$ & 23.7 & $<0.001$ & $19.77 \pm 1.93$ & 17.85 & $<0.001$ \\
\hline & IIA & $25.28 \pm 3.59$ & 4.5 & $<0.001$ & $27.65 \pm 2.18$ & 12.18 & $<0.001$ \\
\hline & IIB & $29.03 \pm 2.65$ & 21.7 & $<0.001$ & $28.67 \pm 3.56$ & 13.85 & $<0.001$ \\
\hline
\end{tabular}

Table 3: Statistical comparison of IOP reduction by different drug in same group.

\begin{tabular}{|c|c|c|c|c|c|c|c|}
\hline \multirow[t]{2}{*}{ Group } & \multirow[t]{2}{*}{ Drug } & \multicolumn{2}{|c|}{$\begin{array}{l}\text { IOP Reduction (mm Hg) } \\
(\text { Mean } \pm \text { SD) }\end{array}$} & \multicolumn{2}{|c|}{ Right eye } & \multicolumn{2}{|c|}{ Left eye } \\
\hline & & Right Eye & Left Eye & t value & p value & t value & p value \\
\hline I A & Dorzolamide hydrochloride (2\%) & $6.2 \pm 1.85$ & $5.55 \pm 1.68$ & \multirow{2}{*}{2.22} & \multirow{2}{*}{$<0.05$} & \multirow{2}{*}{2.18} & \multirow{2}{*}{$<0.05$} \\
\hline IB & Timolol maleate $0.5 \%$ & $5.06 \pm 1.62$ & $4.40 \pm 1.96$ & & & & \\
\hline IIA & Dorzolamide hydrochloride (2\%) & $4.72 \pm 2.97$ & $5.37 \pm 1.24$ & \multirow{2}{*}{0.62} & \multirow{2}{*}{$>0.05$} & \multirow{2}{*}{3.28} & \multirow{2}{*}{$<0.001$} \\
\hline IIB & Timolol maleate $0.5 \%$ & $4.30 \pm 1.41$ & $4.12 \pm 2.08$ & & & & \\
\hline
\end{tabular}


Table 4: Statistical comparison of IOP reduction by same drug in different group.

\begin{tabular}{|c|c|c|c|c|c|c|c|}
\hline \multirow[t]{2}{*}{ Drug } & \multirow[t]{2}{*}{ Group } & \multicolumn{2}{|c|}{$\begin{array}{l}\text { IOP Reduction }(\mathrm{mm} \mathrm{Hg}) \\
(\text { Mean } \pm \text { SD) }\end{array}$} & \multicolumn{2}{|c|}{ Right eye } & \multicolumn{2}{|c|}{ Left eye } \\
\hline & & Right Eye & Left Eye & t value & p value & $t$ value & p value \\
\hline \multirow{2}{*}{$\begin{array}{l}\text { Dorzolamide } \\
\text { hydrochloride (2\%) }\end{array}$} & Gr. IA & $6.2 \pm 1.85$ & $5.55 \pm 1.68$ & \multirow{2}{*}{2.49} & \multirow{2}{*}{$<0.05$} & \multirow{2}{*}{0.31} & \multirow{2}{*}{$<0.05$} \\
\hline & Gr. IIA & $4.72 \pm 2.97$ & $5.37 \pm 1.24$ & & & & \\
\hline \multirow{2}{*}{ Timolol maleate $0.5 \%$} & Gr. IB & $5.06 \pm 1.62$ & $4.40 \pm 1.96$ & \multirow{2}{*}{2.22} & \multirow{2}{*}{$<0.05$} & \multirow{2}{*}{0.27} & \multirow{2}{*}{$<0.05$} \\
\hline & Gr. IIB & $4.30 \pm 1.41$ & $4.12 \pm 2.08$ & & & & \\
\hline
\end{tabular}

Table 5: Effect of dorzolamide and timolol on blood pressure (MEAN \pm SD).

\begin{tabular}{|c|c|c|c|c|}
\hline & \multicolumn{2}{|c|}{ Dorzolamide hydrochloride (2\%) (Mean \pm SD) } & \multicolumn{2}{|c|}{ Timolol maleate $(0.5 \%)($ Mean \pm SD $)$} \\
\hline & $\begin{array}{l}\text { Systolic B.P. } \\
\text { (mm Hg) }\end{array}$ & $\begin{array}{l}\text { Diastolic } \\
\text { B.P. }(\mathbf{m m ~ H g})\end{array}$ & $\begin{array}{l}\text { Systolic B.P. } \\
(\mathrm{mm} \mathrm{Hg})\end{array}$ & $\begin{array}{l}\text { Diastolic } \\
\text { B.P. }(\mathrm{mm} \mathrm{Hg})\end{array}$ \\
\hline Pre-treatment & $129.75 \pm 5.34$ & $82.25 \pm 4.20$ & $131.0 \pm 10.69$ & $85.86 \pm 5.69$ \\
\hline End of week 24 & $127.0 \pm 4.78$ & $79.75 \pm 3.10$ & $126.0 \pm 10.05$ & $82.57 \pm 5.05$ \\
\hline Difference & $2.75 \pm 3.37$ & $2.5 \pm 2.07$ & $5.0 \pm 3.48$ & $3.29 \pm 2.78$ \\
\hline t- value & 2.31 & 3.42 & 5.37 & 4.42 \\
\hline p- value & $<0.05$ & $<0.05$ & $<0.001$ & $<0.001$ \\
\hline
\end{tabular}

In Table 4, mean reduction of IOP after 24 weeks in Group IA and IIA and Group IB and IIB was significant in both the eyes.

In Table 5, dorzolamide mean systolic and diastolic blood pressure was $129.75 \pm 5.34$ and $82.25 \pm 4.20 \mathrm{~mm} \mathrm{Hg}$ and 127.0 \pm 4.78 and $79.75 \pm 3.10 \mathrm{~mm} \mathrm{Hg}$ at pre-treatment and at the end of $24^{\text {th }}$ week respectively. In Timolol group mean systolic and diastolic blood pressure was 131.0 \pm 10.69 and $85.86 \pm 5.69 \mathrm{~mm} \mathrm{Hg}$ and $126.0 \pm 10.05$ and $82.57 \pm 5.05 \mathrm{~mm}$ $\mathrm{Hg}$ at pre-treatment and at the end of $24^{\text {th }}$ week respectively.

Table 6: Effect of dorzolamide and timolol on heart rate $(\mathrm{MEAN} \pm \mathrm{SD})$.

\begin{tabular}{|lll|}
\hline & $\begin{array}{l}\text { Dorzolamide } \\
\text { hydrochloride } \\
(2 \%) \text { (Beats / } \\
\text { min.) } \\
(\text { Mean } \pm \text { SD) }\end{array}$ & $\begin{array}{l}\text { Timolol } \\
\text { maleate 0.5\% } \\
\text { (Beats / min.) } \\
(\text { Mean } \pm \text { SD) }\end{array}$ \\
\hline Pre-treatment & $76.75 \pm 6.23$ & $78.17 \pm 3.12$ \\
\hline End of week 24 & $75.0 \pm 7.09$ & $74.17 \pm 3.66$ \\
\hline Difference & $1.87 \pm 1.55$ & $4.0 \pm 2.26$ \\
\hline t- value & 3.41 & 6.14 \\
\hline p- value & $<0.01$ & $<0.001$ \\
\hline
\end{tabular}

There was a significant fall in both systolic and diastolic blood pressure in Dorzolamide group at the end of week 24. But Timolol group showed more significant fall in systolic and diastolic blood pressure at the end of week 24 .

In Table 6, mean pre-treatment heart rate of $76.75 \pm 6.23$ beats/min and $78.17 \pm 3.12$ beats/min in Dorzolamide and Timolol group respectively. At the end of 24 weeks of treatment there was a mean reduction of $1.87 \pm 1.55$ in Dorzolamide group and $4.0 \pm 2.26$ beats/ min in Timolol group.

\section{DISCUSSION}

Timely and adequate control of glaucoma is very important to prevent further silent loss of vision. The treatment of glaucoma is primarily directed towards lowering intra ocular pressure. This can be brought about by conservative medical treatment, laser therapy or by surgery.

In Table 2, Group IA- Mean IOP before starting the treatment and at the end of 24 weeks of treatment was $27.02 \pm 3.86 \mathrm{~mm} \mathrm{Hg}$ and $20.82 \pm 2.46 \mathrm{~mm} \mathrm{Hg}$ in right eye and $25.95 \pm 2.16 \mathrm{~mm} \mathrm{Hg}$ and $20.40 \pm 1.60 \mathrm{~mm} \mathrm{Hg}$ in left eye respectively. In Group IIA, Mean IOP before starting the treatment and at the end of 24 weeks of treatment were $30.0 \pm 6.31$ and $25.28 \pm 3.59 \mathrm{~mm} \mathrm{Hg}$ in the right eye and $33.02 \pm 1.09$ and $27.65 \pm 2.18 \mathrm{~mm} \mathrm{Hg}$ in the left eye respectively.

Julia A Balfour and Michelle J Wilde reported in clinical trials in patients with open angle glaucoma or ocular hypertension, Dorzolamide hydrochloride (2\%) 3 times daily generally lower intraocular pressure by approximately 4-6mm $\mathrm{Hg}$ at peak (2-hour post dose) and $3-4.5 \mathrm{~mm} \mathrm{Hg}$ at trough ( 8 hours post dose). Overall the percent reduction at the IOP from the baseline at the end of treatment period was $9.81 \%$ at trough and $20.80 \%$ at peak drug levels by monotherapy. ${ }^{11}$ A. Scardillo reported $20 \%$ reduction of IOP after instillation of $2 \%$ Dorzolamide hydrochloride three times daily into the conjunctival sac of affected eyes. $^{12}$ 
According to Table 3 mean reduction of IOP was $6.2 \pm 1.85 \mathrm{~mm} \mathrm{Hg}$ and $5.55 \pm 1.68 \mathrm{~mm} \mathrm{Hg}$ in the right and left eye respectively in Group IA at the end of 24 weeks of treatment. In Group IIA, mean reduction of IOP was $4.72 \pm 2.97 \mathrm{~mm} \mathrm{Hg}$ and $5.37 \pm 1.24 \mathrm{~mm} \mathrm{Hg}$ in the right and left eye respectively at the end of 24 weeks of treatment. In Group IB, mean IOP before and at the end of 24 weeks of treatment were $25.93 \pm 3.67$ and $20.87 \pm 2.54 \mathrm{~mm} \mathrm{Hg}$ in right eye and $24.17 \pm 2.07$ and $19.77 \pm 1.93 \mathrm{~mm} \mathrm{Hg}$ in left eye respectively. In Group IIB, the mean IOP before and at the end of 24 weeks of treatment were $33.33 \pm 2.53$ and $29.03 \pm 2.65 \mathrm{~mm} \mathrm{Hg}$ in right eye and $32.79 \pm 4.31$ and $28.67 \pm 3.56 \mathrm{~mm} \mathrm{Hg}$ in the left eye respectively. There was significant difference in the mean reduction of IOP in the present study.

Ayman A, Hamed M, Hany A, Salem and Mostafa AH reported a mean IOP reduction ranging from 3.8 to $5.1 \mathrm{~mm}$ $\mathrm{Hg}$ by Timolol maleate $0.5 \%$ in 14 patients for 4 weeks. ${ }^{13}$

In another study by Melamed S and David R in 2000 on 46 patients receiving Timolol maleate $0.5 \%$ reported a mean IOP reduction of $5.57 \mathrm{~mm} \mathrm{Hg}$. Also reported a mean reduction of IOP ranged from 5.8 to $6.6 \mathrm{~mm} \mathrm{Hg}$ at 2-hour peak. At 12-hour trough the Timolol group had mean IOP lowering ranging from 3.8 to $4.8 \mathrm{~mm} \mathrm{Hg}{ }^{14}$

According to Table 4, mean reduction of IOP was $6.2 \pm 1.85 \mathrm{~mm} \mathrm{Hg}$ and $5.55 \pm 1.68 \mathrm{~mm} \mathrm{Hg}$ in the right and left eye respectively in Group IA at the end of 24 weeks of treatment. In Group IIA, mean reduction of IOP was $4.72 \pm 2.97 \mathrm{~mm} \mathrm{Hg}$ and $5.37 \pm 1.24 \mathrm{~mm} \mathrm{Hg}$ in the right and left eye respectively at the end of 24 weeks of treatment. Mean reduction of IOP was $5.06 \pm 1.62 \mathrm{~mm} \mathrm{Hg}$ and $4.40 \pm 1.96 \mathrm{~mm} \mathrm{Hg}$ in the right and left eye respectively in Group IB at the end of 24 weeks of treatment. In Group IIB, mean reduction of IOP was $4.30 \pm 1.41 \mathrm{~mm} \mathrm{Hg}$ and $4.12 \pm 2.08 \mathrm{~mm} \mathrm{Hg}$ in the right and left eye respectively at the end of 24 weeks of treatment. There was significant difference of mean IOP reduction between the present study and the study conducted earlier by the abovementioned authors.

Insufficient responses i.e. the IOP reduction of less than $10 \%$ at the end of week 2 , was seen in 1 patient in Group IA, 2 patients in Group IB, 1 patient in Group IIA and 2 patients in Group IIB. 2 patients, one from Group IA and other from Group IIA did not turn-up after week 4. All of those patients were excluded from further study.

According to Table 5, there was significant fall in both systolic and diastolic blood pressure in both the groups. However, fall of mean blood pressure was more in Timolol group than Dorzolamide group. A similar and significant decrease of mean pressure without clinical symptoms were noted by Derick RJ et al. ${ }^{15}$

In Table 6, mean pre-treatment heart rate of $76.75 \pm 6.23$ beats/min and $78.17 \pm 3.12$ beats/min in Dorzolamide and Timolol group respectively. At the end of 24 weeks of treatment there was a significant mean reduction of $1.87 \pm 1.55$ beats/min in Dorzolamide group and 4.0 \pm 2.26 beats/ $\mathrm{min}$ in Timolol group.

Both drug regimens were well-tolerated, and no serious drug-related adverse effects were reported. In present study 3 patients who were hypertensive and 2 patients who were asthmatic were on Dorzolamide and showed no exaggeration of these systemic problems.

In the present study, ocular burning sensation, ocular stinging sensation and bitter taste were reported significantly and more frequently in patients receiving Dorzolamide hydrochloride $2 \%$ while ocular irritation and dryness of mouth reported more often in timolol treated patients. Ellen Strahman et al, reported in 1995, the most frequently reported symptom among patients receiving Dorzolamide was bitter taste (27\%) compared with smaller proportion of patients receiving timolol $(7 \%) .{ }^{16}$

\section{CONCLUSION}

Dorzolamide had an edge over Timolol as far as reduction of intra ocular pressure in concerned. Dorzolamide was well-tolerated, low allergic response and had a favourable ocular and systemic safety profile. Dorzolamide had lesser effect on cardiovascular parameters than Timolol and can be used safely in patients with asthmatic and chronic obstructive pulmonary disease.

Funding: No funding sources

Conflict of interest: None declared

Ethical approval: The study was approved by the Institutional Ethics Committee

\section{REFERENCES}

1. Weinreb RN, Aung $\mathrm{T}$, Medeiros FA. The Pathophysiology and Treatment of Glaucoma: A Review. JAMA. 2014 May 14;311(18):1901-11.

2. Mishima S, Masuda K, Tamura T. Chapter 4. Drugs Influencing Aqueous Humor Formation and Drainage. Dikstein S (ed): Drugs and Ocular Tissues. 2nd Meeting of the International Society for Eye Research, Jerusalem, September 1976: Proceedings. Basel, Karger, 1977:128-287.

3. Goel M, Picciani RG, Lee RK, Bhattacharya SK. Aqueous Humor Dynamics: A Review. Open Ophthalmol J. September 2010;4:52-9.

4. Thomas R, Loibl K, Parikh R. Evaluation of a glaucoma patient. Indian J Ophthalmol. 2011 Jan;59(1):S43-52.

5. Smith SD, Singh K, Lin SC, Chen PP, Chen TC, Francis BA, et al. Evaluation of the Anterior Chamber Angle in Glaucoma. A Report by the American Academy of Ophthalmology. Ophthalmology, Volume 120, Number 10, October 2013:1985-1997.

6. Bunga T. A clinical study on management of primary open angle glaucoma. Inte $\mathrm{J}$ of Inf Res and Revie. 2015;2(2):416-9. 
7. Katz IM, Hubbard WA, Getson AJ, Gould AL. Intraocular pressure decreases in normal volunteers following timolol ophthalmic solution. Investigative Ophthalmology and Visual Science. June 1976;15:489-92.

8. Radius RL, Diamond GR, Pollack IP, Langham ME. Tirnolol A new Drug for management of chronic simple glaucoma Arch. Ophthal. (Chicago) 1978;96:1003-8.

9. Hoste AM. Beta-Blockers. In Tarek Shaarawy, Mark B. Sherwood, Roger A. Hitchings and Jonathan G. Crowston editors. Glaucoma ( $2^{\text {nd }}$ Edition). 2015;1:548-558 (Available online 2 September 2014).

10. Rosenberg LF, Krupin T, Tang LQ, Hong PH, Ruderman JM. Combination of systemic acetazolamide and topical dorzolamide in reducing intraocular pressure and aqueous humor formation. Ophthalmology. 1998 Jan;105(1):88-93.

11. Balfour JA, Wilde MI. Dorzolamide. A Review of its Pharmacology and Therapeutic Potential in the Management of Glaucoma and Ocular Hypertension. Drugs and Aging. May 1997;10(5):384-403.

12. Scardillo A, Pugliese M, De Majo M, Niutta PP, Pugliese A. Effects of Topical $0.5 \%$ Levobunolol Alone or in Association With 2\% Dorzolamide Compared with a Fixed Combination of $0.5 \%$ Timolol and $2 \%$ Dorzolamide on Intraocular Pressure and
Heart Rate in Dogs Without Glaucoma. Veterinary Therapeutics. 2010;11(3):E1-E6.

13. Hamed AA, M. Salem HA, Haikal MA. Apraclonidine versus Timolol eye drops of management of Openangle glaucoma. Bull. Ophthalmol Soc. Eqypt. 1997;90(2):243-6.

14. Melamed S, David R. Ongoing clinical assessment of the safety profile and efficacy of brimonidine compared with timolol: year-three results. Brimonidine Study Group II. Clinical therapeutics. 2000 Jan; 22(1):103-11.

15. Derick RJ, Robin AL, Waltersb TR, Barnebey HS, Choplin N, Schuman J, et al. Brimonidine tartrate: a one-month dose response study. Ophthalmology. January 1997;104(1):131-6.

16. Strahlman E, Tipping R, Vogel R. A Double-Masked, Randomized 1-Year Study Comparing Dorzolamide (Trusopt), Timolol, and Betaxolol. Arch Ophthalmol. 1995;113(8):1009-16.

Cite this article as: Chandra A, Kumar M, Mishra AN. Efficacy and safety of topical $2 \%$ dorzolamide and $0.5 \%$ timolol in cases of open angle glaucoma in a tertiary care hospital of East Singhbhum: an observational, prospective and comparative study. Int J Basic Clin Pharmacol 2018;7:1303-8. 